УдК 903.21 (477.7) Ольвія

DOI: https://doi.org/10.33782/eminak2021.1(33).500

\title{
ОДИН ТИП КІСТЯНИХ АРТЕФАКТІВ 3 ОЛЬВІЇ ТА ЙОГО ІНТЕРПРЕТАЦІЯ
}

\author{
Аліса Семенова \\ Інститут археології Національної академії наук України (Київ, Україна) \\ e-mail: semenovaalise@gmail.com \\ ORCID: https://orcid.org/0000-0002-0809-3681
}

\begin{abstract}
У статті розглядається одна з найчисельніших категорій кістяних артефактів з Ольвії - модифікованих довгих кісток великих свійських тварин з рядами насічок на робочій поверхні. Довгий час їх помилково вважали знаряддями для обробки кераміки, кістки, вичинки шкур і навіть шліфування каменю. Справжнє ж їх призначення, як підставокнаковань для нанесення зубців на гофрований серп, вдалося встановити за допомогою численних даних етнографії.
\end{abstract}

Ключові слова: Північне Причорномор'я, Ольвія, кістяні наковані, ремесло, землеробство

Дослідження виробів з кістки та рогу часто викликає у дослідників великі труднощі через те, що важко точно визначити справжнє функціональне призначення того чи іншого артефакту. У деяких випадках, наприклад - в таких, як ми опишемо у статті, цю проблему дозволяють вирішити дані етнографії.

Одна з найчисленніших в Ольвії категорій готових виробів з органічної сировини відома у радянській, а згодом - і українській, науковій літературі під терміном «рашпіль».

Сировиною для цих артефактів, здебільшого, слугували довгі (плюснові, п’ясні та великі гомілкові), рідше - пласкі (щелепні), кістки великих свійських тварин коня та бика. Ще рідше для цих цілей використовували ріг оленя. Виготовлені 3 довгих кісток великих ссавців знаряддя, як правило, спочатку вирівнювали за допомогою підтиски діафізу. Оброблялися вони з однієї або кількох анатомічних сторін кістки, зі збереженням або частковим чи повним вирівнюванням епіфізів. В останньому випадку вироби за формою наближались до паралелепіпеда.

Характерною ознакою для всіх цих знарядь, незалежно від сировини та ступеню модифікації, є специфічні сліди на робочій поверхні - ряди паралельних або хаотичних ліній насічок підтрикутної форми. Нанесені вони, очевидно, якимось тонким гострим інструментом. У випадку, коли «рашпілі» були виготовлені з метаподіалів, розрізняються знаряддя з однією, двома, трьома або чотирма робочими поверхнями. Значна кількість таких артефактів дійшли до нас у зламаному, очевидно - у процесі експлуатації - вигляді. Відомі випадки кількаразового використання одного знаряддя, коли після того, як воно втрачало необхідні для роботи якості, робоча поверхня повторно вирівнювалася та використовувалась знову.

Такі знаряддя походять з багатьох античних пам'яток Північного Причорномор'я та скіфських поселень і відносяться до трьох хронологічних періодів - класичного, елліністичного та римського. Єдині, на сьогодні, достовірно датовані 
класичним часом «рашпілі» походять з приміських садиб Ольвії1. Елліністичний період репрезентують знахідки з наступних пам'яток: Ольвія ${ }^{2}, \mathrm{Xерсонес}^{3}$, Тірітака4, Горгіпія та Більське городище 5 . Римським часом датуються знахідки з Ольвії6, Козирського городища7, Фанагорії8, поселень Семенівка9 та Михайлівка ${ }^{10}$, городища Чайка у Західній Тавриці та воєнного форпосту Дубки 11.

Окрім того, відомі знахідки з широкою хронологією, датовані античним часом: Кепи ${ }^{12}$, Неаполь Скіфський ${ }^{13}$, Артезіан, Кара-Тобе ${ }^{14}$, Ніконій і Надлиманське городище ${ }^{15}$. У всіх означених випадках датування базувалося на пов'язаному з «рашпілями» археологічному контексті, адже радіовуглецевий аналіз не застосовувався до жодної знахідки з Північного Причорномор'я.

Щодо функціонального призначення цих виробів було висловлено низку гіпотез. Так, В.Ф.Гайдукевич, відповідно до контексту знахідки кістяного знаряддя під час розкопок гончарних горнів у Фанагорії, припускав, що воно могло використовувалось у гончарному виробництві, а саме - як інструмент для формовки жолобчастих ручок амфор ${ }^{16}$.

Інше найбільш поширене у радянській та українській історіографії тлумачення вперше запропонував Г.Д.Бєлов. Описуючи знахідки елліністичного часу в Херсонесі, він згадав знаряддя, яке, на його думку, слугувало для шліфування мармурових виробів, скульптури та архітектурних деталей. Своє припущення він аргументував тим, що насічки цього виробу були заповнені піщинками, які слугували абразивом ${ }^{17}$.

\footnotetext{
1 Папанова В.А., Ляшко С.Н. Костяные изделия из пригородных усадеб Ольвии // Емінак. 2016. № 4. C. 179.

${ }^{2}$ Семенов С.А. Шліфувальні кістяні знаряддя з Ольвії // Археологічні пам’ятки УРСР. 1958. № 7 C. 92.

3 Белов Г.Д., Стржелецкий С.Ф., Якобсон А.Л. Квартал XVIII (Раскопки 1941, 1947 и 1948 гг.) // Материалы и исследования по археологии СССР. 1953. N 34. С. 195; Кадеев В.И. Очерки истории экономики Херсонеса Таврического в I-V веках н.э. Харьков. 1970. С. 127.

4 Гайдукевич В.Ф. Раскопки Тиритаки и Мирмекия в 1946-1952 гг. // Материалы и исследования по археологии СССР. 1958. № 85. С. 157.

5 Антипина Е.Е. Последам костяных «рашпилей» из античных памятников Северного Причерноморья // Причернорье в античное и раннесредневековое время. Сборник научных трудов, посвященный 65-летию профессора Копылова. Ростов-на-Дону. 2013. С. 383.

6 Крапивина В.В. Ольвия. Материальная культура I-IV вв. н.э. Киев: Наукова думка, 1993. С. 136.

7 Бураков А.В. Козырское городище рубежа и первых столетий нашей эры. Киев: Наукова думка, 1976. С. 126.

8 Гайдукевич В.Ф. Античные керамические обжигательные печи по раскопкам в Керчи и Фанагории в 1929-1931 гг. // Известия Государственной академии материальной истории и культуры. Москва-Ленинград. 1934. № 80. С. 88.

${ }^{9}$ Кругликова И.Т. Боспор в Позднеантичное время (Очерки экономической истории). Москва: Наука, 1966. С. 52.

10 Петерс Б.Г. Косторезное дело в античных государствах Северного Причерноморья. Москва: Наука, 1986. С. 42.

11 Антипина Е.Е. Последам костяных «рашпилей» из античных памятников... С. 385.

12 Петерс Б.Г. Косторезное дело в античных государствах... С. 42.

13 Высотская Т.Н. Неаполь - столица государства поздних скифов. Київ: Наукова думка, 1979. C. 124.

${ }^{14}$ Антипина Е.Е. Последам костяных «рашпилей» из античных памятников... С. 385.

15 Бруяко И.В., Секерская Е.П. Очерки экономики населения Северо-западного Причерноморья в античную епоху. Одесса: Ирбис, 2016. С. 154.

16 Гайдукевич В.Ф. Античные керамические обжигательные печи... С. 88.

17 Белов Г.Д., Стржелецкий С.Ф., Якобсон А.Л. Квартал XVIII... С. 196.
} 
Розвиток ця ідея отримала у дослідженнях С.А. Семенова, який опрацював колекцію з 48 однотипних виробів з Ольвії. Вони були визначені ним як шліфувальні знаряддя й отримали назву «рашпілі», по аналогії з сучасними металевими рашпілями. Саме ця назва надалі використовувалася для опису означених виробів у науковій літературі на теренах колишньої СРСР.

До такого визначення виробів автор дійшов завдяки трасологічному дослідженню робочих поверхонь артефактів, на яких фіксувалися подряпини, орієнтовані у тому ж напрямку, що і ряди насічок. Такі подряпини, на думку автора, вказують на те, що кістяними знаряддями оброблявся дуже твердий матеріал. С.А. Семенов припускав, що трикутні насічки слугували для того, щоб затримувати пісок, який використовувався як абразив; він же (пісок) і залишав на поверхні згадані вище подряпини. Завдяки такому абразиву можна було обробляти дуже тверді породи каменю. Давній майстер використовував збережені епіфізи як природні ручки, за які він тримався при роботі. Для підтвердження своєї теорії автор провів експеримент, обробивши подібним чином телячу кістку, й опускаючи її почергово у воду та пісок, відшліфував поверхню плити сірого мармуру18.

Надалі більшість авторів слідуючи за Г.Д. Бєловим і С.А. Семеновим визначали такі артефакти як знаряддя для шліфування, але припускали, що використовуватись вони могли не лише для каменю. В.І. Кадєєв висловлював думку, що «рашпілі» могли також застосовуватися як знаряддя для первинної обробки кістки ${ }^{19}$, Т.М. Висотська вважала, що знайдені на скіфських городищах екземпляри частіше застосовувались для вичинки шкір 20 . Б.Г. Петерс, автор найбільш повної монографії, присвяченої косторізній справі Північного Причорномор'я, підсумовуючи попередні дослідження, відзначав, що «рашпілі» були поліфункціональними знаряддями для шліфовки різних об'єктів 21.

Зовсім іншу думку запропонувала А.А. Моруженко, припускаючи, що подібні артефакти могли використовуватися в якості підставок або наковань 22 , про що свідчить велика кількість дрібних насічок ${ }^{23}$. Ніякої іншої аргументації авторка не навела, але ця здогадка згодом отримала підтвердження в етнографічних матеріалах за межами Чорноморського регіону.

Таким чином, з часу публікації перших таких знахідок було запропоновано чимало варіантів інтерпретації цих предметів, проте дослідження в основному обмежувалися даними радянської, а згодом - української та російської території. У той же час, подібні знахідки мали місце і на інших територіях і мають як археологічний, так і етнографічний контекст.

Коротко про ці дослідження згадує К.Є. Антипіна, подаючи як доведений факт те, що артефакти, які раніше вважалися «рашпілями», з огляду на нові дані слід визначати як кістяні наковані для виготовлення гофрованих серпів. Проте, і піс-

18 Семенов С.А. Шліфувальні кістяні знаряддя з Ольвії... С. 9596.

${ }^{19}$ Кадеев В.И. Очерки истории экономики Херсонеса Таврического... С. 127.

20 Высотская Т.Н. Неаполь - столица государства... С. 124.

21 Петерс Б.Г. Косторезное дело в античних... С. 43.

22 Моруженко використовує термін «наковаленка», а в англомовній літературі використовується термін «anvil».

Словник Грінченка пропонує два варіанти «ковадло» та «наковань», останній більш доречний, адже буквально означає маленьке ковадло.

23 Моруженко А.А. К вопросу о памятниках раннего желейного века в басейне р. Ворскла // Советская археология. 1988. № 1. С. 44. 
ля цієї публікації українські дослідники продовжують користуватися терміном «рашпіль» і схилятись до думки, що використання їх як шліфувальних знарядь $\epsilon$ найбільш переконливим. 3 огляду на це, вважаємо за необхідне детальніше зупинитися на археологічних i, передусім, етнографічних аналогіях за межами Північно-Причорноморського регіону.

Знахідки подібних артефактів зафіксовані на гетських пам'ятках Молдови $24, \mathrm{y}$ римських шарах Істрії (Румунія)25, Вимінаціума (Сербія) 26 та, можливо, у Полентії (о. Мальорка) 27 ; останні, на жаль, не мають достатньої інформації про контекст знахідки.

Наразі тільки два кістяні наковані були продатовані за допомогою радіовуглецевого аналізу. Перший походить з Метапонта (Італія) і датується 190 рр. до н.е. - 10 pp. н.е. 28 , а другий - з Монтефі (о. Менорка, Іспанія) та датується між 24 i 213 рр. н.е., що співпадає з попереднім датуванням за супутнім археологічним матеріалам 29.

Більш пізні знахідки походять з територій Угорщини, Іспанії, Франції, Португалії та деяких країн Північної Африки, і хронологічно охоплюють час від Середньовіччя аж до середини XX ст. Довгий час із визначенням функціонального призначення цих кістяних виробів виникали великі труднощі, а ключем до розв'язання проблеми стали саме етнографічні дослідження. 3 кожним роком залучаються все нові дані, що були зібрані як на початку XX ст. (безпосередньо у ковалів, які професійно займались заточкою гофрованих серпів), так і в сучасних майстрів, які підтримують напрямки традиційного ковальства.

У колекції музею Сан-Тельмо (Іспанія) зберігається придбаний у 1916 р. набір для заточки серпів, в який входили стіл, молоток, зубчастий серб і дві кістки бика. Ці кістяні вироби виявилися ідентичними деяким іншим етнографічним та археологічним матеріалам. Окрім самих предметів, у музеї зберігалися фотографія коваля за роботою й опис виготовлення гофрованого серпа (рис. 1), записаний зі слів коваля з Іцасондо, який помер 1981 р.

3 опису слідувало, що на етапі охолодження серпа після кування майстер переходив до формування зубців. Для цього він сідав на спеціальний стілець з квадратним отвором, куди вводився дерев'яний клин, на який клали оброблену довгу кістку коня чи бика, а зверху - серп. Вся ця конструкція закріплювалася за допомогою шкіряного ременя, вільний кінець якого майстер фіксував ногою. Потім за допомогою легких ударів молотка по спеціальній гострій і тонкій стамесці відбувалося власне формування зубців, кожен такий удар залишав слід на кістці.

\footnotetext{
24 Никулицэ И.Т.Северные фракийцы в VI-I вв. до н.э. Кишинев: Штиинца, 1987. С. 100.

25 Beldiman C., Rusu-Bolindeț V., Sztancs D.M., Bădescu A. Bone artefacts from Histria // Materiale şi cercetări Arheologice. 2014. № 10. P. 222-223.

26 Vukovic Bogdanovic S., Bogdanović I. Late Roman Bone Anvils from Viminacium // Close to the bone: current studies in bone technologies, edited by S. Vitezović. Belgrade: Institute of Archaeology, 2016. P. 66.

27 Valenzuela A., Moreno-García M., Oliver A. Archaeological and ethnographic insights on the occurrence and use of bone anvils in Mallorca (Balearic Islands, Spain) // Cuadernos de Prehistoria y Arqueología de la Universidad de Granada. 2019. № 29. P. 296.

28 Gál E, Bartosiewicz L. A radiocarbon-dated bone anvil from the chora of Metaponto, southern Italy // Antiquity. 2012. № 86 (331). URL: http://antiquity. ac.uk/projgall/gal331/

29 Valenzuela A., Cau M., León M. Broadening the Scope of Bone Anvils: Direct AMS 14C Dating from the Island of Menorca (Western Mediterranean) // Radiocarbon. 2017. № 59 (1). P. 64.
} 
Використання саме кістки при формуванні гофрованих серпів пов’язано з її пружними властивостями, що запобігає пошкодженню стамески ${ }^{30}$.

Подібний вид діяльності також був зафіксований у селі Сінеу Йозефом Понс Фрау, який займався дослідженням і фіксацією сільського життя на Майорці, на початку XX ст. та опублікований в альбомі «Mallorca: Photographic and ethnographic images». Збереглися фотографії за роботою та інтерв'ю жінки, яка займалась заточкою гофрованого серпа 31 .

Ще один приклад виготовлення гофрованих серпів за допомогою підставок 3 довгих кісток великої рогатої худоби, відомий із сучасних досліджень на північному заході Тунісу. Тут фермери і сьогодні використовують серпи з зазубреним краєм, які виготовляються схожим способом, що зафіксований у піренейській етнографії ${ }^{32}$.

Всі ці етнографічні аналогії цілком впевнено свідчать про те, що кістяні вироби з археологічних пам'яток слугували саме як кістяні наковані для заточки гофрованих серпів. Зараз, після того як більшість дослідників погодилися з такою інтерпретацією, виникла необхідність зосередити увагу на питаннях географічного та хронологічного поширення цих артефактів. Адже мова йде не тільки про технологію виробництва металевих серпів, але й про специфіку сільського господарства, а також про взаємозв'язок різних складових економіки (металообробки, косторізного ремесла та землеробства). Знахідки кістяних накованей опосередковано вказують на існування залізних серпів із зубчатим краєм, тому що на античних пам'ятках Північного Причорномор'я такі серпи поки не були знайдені33. Така ж ситуація спостерігається і поза межами Чорноморського басейну, що може бути пояснене загальною поганою збереженістю металів, а особливо таких крихких частин як зубціз3.

Цікавою є знахідка фрагменту кістяного накованя серед матеріалу воєнного форпосту римського часу Дубки, який очевидно ніяк не був пов'язаний з землеробством ${ }^{35}$. Можна припустити, що подібна методика обробки могла застосовуватися і до інших металевих виробів, наприклад пил.

Серп 3 гофрованим краєм набагато більш ефективний за серп 3 гладким лезом, він не потребує постійної заточки, хоча зубці час від часу потрібно відновлювати ${ }^{36}$.

Згідно із сучасними відомостями, така інновація як серп з гофрованим краєм з'явився в античному світі спочатку в містах Північного Причорномор'я. Після встановлення справжнього функціонального призначення цих артефактів постійно з'являються нові відомості й очевидно, що географія поширення кістяних накованей буде розширюватись, а хронологія - уточнюватись.

Таким чином, завдяки використанню даних етнографії вдалося встановити

\footnotetext{
30 Aguirre A., Etxeberria F., Herrasti L. El yunque de hueso para afilar la hoz metálica dentada. Munibe, 2004. P. 114-115.

31 Valenzuela A., Moreno-García M., Oliver A. Archaeological and ethnographic insights... P. 302.

32 Anderson P.C., Rodet-Belarbi I., Moreno-García M. Sickles with teeth and bone anvils // van Gijn A., Whittaker J., Anderson P.J. (eds). Exploringand Explaining Diversity inAgricultural Technology. Oxford: Oxbow Books, 2014. Р. 118-125.

33 Антипина Е.Е. Последам костяных «рашпилей» из античных памятников... С. 387.

34 Gál E., Bartosiewicz L. A radiocarbon-dated bone anvil...

35 Антипина Е.Е. Последам костяных «рашпилей» из античных памятников... С. 386.

36 Anderson P.C., Rodet-Belarbi I., Moreno-García M. Sickles with teeth and bone anvils... P. 119.
} 
справжнє функціональне призначення виробів, які були знайдені в Ольвії та на інших пам'ятках античного, середньовічного та ранньомодерного часу. Цей приклад, як і деякі інші, ілюструють специфіку косторізного ремесла як дуже архаїчного, коли способи обробки та певні форми залишаються сталими протягом дуже тривалого часу і підтверджують доцільність використання етноархеологічних методів в інтерпретації археологічних джерел.

\section{REFERENCES}

Aguirre, A, Etxeberria, F. \& Herrasti, L. (2004). El yunque de hueso para afilar la hoz metálica dentada [Bone anvils used for sharpening serrated, metal scythes]. Munibe 56. 113-121 [in Spanish].

Anderson, P.C., Rodet-Belarbi, I. \& Moreno-García, M. (2014). Sickles with teeth and bone anvils. In van Gijn, A., Whittaker, J. \& Anderson, P.J. (Eds.). Exploringand Explaining Diversity in Agricultural Technology. Oxford: Oxbow Books, pp. 118-125 [in English].

Antipina, E. (2013). Po sledam kostianykh «rashpilei» iz antichnykh pamiatnikov Severnogo Prichernomoria [Following bones «rasps» from the antic cities of Northern Black Sea Region]. Prichernorie v antichnoe i rannesrednevekovoe vremia. Rostov-na-Donu, pp. 384-388 [in Russian].

Beldiman, C., Rusu-Bolindeț, V., Sztancs, D.M. \& Bădescu, A. (2014). Bone artefacts from Histria. Materiale și cercetări Arheologice, 10, 221-241 [in English].

Beldiman, C., Sztancs, D.M., Rusu-Bolineț, V. \& Achim, I.A. (2011). Skeletal technologies, metalworking and wheat harvesting: ancient bone and antler anvils for manufacturing saw-toothed iron sickles discovered in Romania. In Baron, J., Kufel-Diakowska, B. (Eds). Written in Bones. Studies on Technological and Social Contexts of Past Faunal Skeletal Remains. Wrocław: Uniwersytet Wrocławski, pp. 173-186 [in English].

Belov, G., Strzheletskii, S. \& Yakobson, A. (1953). Kvartal XVIII(Raskopki 19411947 i 1948 gg). [Quarter XVIII. (Excavations 1941, 1947 and 1948)]. Materialy i issledovaniia po arkheologii SSSR, 34. 160-237 [in Russian].

Bruyako, I. \& Sekerskaya, E. (2016). Ocherki ekonomiki naseleniia Severo-zapadnogo Prichernomoria $v$ antichnuiu epokhu [Essays on the economy of the population of the North-West Black Sea region in antiguity]. Odessa [in Russian].

Burakov, A. (1976). Kozyrskoe gorodishche rubezha i pervykh stoletii nashei ery [Kozyr hillfort of the turn and the first centuries of our era]. Kyiv: Naukova Dumka. [in Russian].

Gaidukevich, V. (1934). Antichnye keramicheskie obzhigatelnye pechi po raskopkam v Kerchi i Fanagorii v 19291931 gg. [Antique ceramic kilns from excavations in Kerch and Fanagoria in 1929 1931]. Izvestiia Gosudarstvennoi akademii materialnoi istorii i kultury. Moskva-Leningrad [in Russian].

Gaidukevich, V. (1958). Raskopki Tiritaki i Mirmekiia 1946-1952 gg. [Excavations of Tiritaki and Mirmekii in 1946-1952]. Materialy i issledovaniia po arkheologii SSSR, 85, 157-218 [in Russian].

Gál, E. \& Bartosiewicz, L. (2012). A radiocarbon-dated bone anvil from the chora of Metaponto, Southern Italy. Antiquity, 86 (331). Retrieved from http://antiquity.ac.uk/projgall/gal331/ [in English].

Kadeev, V. (1970). Ocherki istorii ekonomiki Khersonesa Tavricheskogo v I-IVvv. n.e. [Essays on the History of the Economy of Chersonesos Tauricus in the $1^{\text {st }}-4^{\text {th }}$ centuries AD]. Kharkov: Izdatelstvo Kharkovskogo universiteta [in Russian].

Krapivina, V. (1993). Olviia. Materialnaia kultura I-IV vv. n.e. [Olbia. The Material Culture of the $1^{\text {st }}-4^{\text {th }}$ centuries AD]. Kiev: Naukova dumka [in Russian].

Kruglikova, I. (1966). Bospor v Pozdneantichnoe vremia Ocherki ekonomicheskoi istorii [The Bosporus in the Late Antiquity (Essays on Economic History)]. Moskva: Nauka[in Russian].

Moruzhenko, A. (1988). K voprosu o pamiatnikakh rannego zheleinogo veka v baseine r Vorskla [On the early Iron Age sites in the Vorskla basin]. Sovetskaia Arkheologiia, 1, 33-52 [in Russian].

Nikulitse, I. (1987). Severnye frakiitsy $v$ VI-I $v v$ do n.e. [Northern Thracians in the VI-I centuries BC]. Kishinev: Shtiintsa [in Russian].

Papanova, V. \& Liashko, S. (2016). Kostianye izdeliia iz prigorodnykh usadeb Olvii [Bone objects of the suburban estates Olvia choirs]. Eminak, 4, 178-188 [in Russian].

Peters, B. (1986) Kostoreznoe delo v antichnykh gosudarstvakh Severnogo Prichernomoria [Bone carving in the ancient states of the Northern Black Sea region]. Moskva: Nauka [in Russian].

Semenov, S. (1958). Shlifuvalni kistiani znariaddia z Olvii [Bone grinding tools from Olbia]. 
Arkheolohichni pamiatky URSR, (Vol. VII, pp. 92-97). Kyiv: Vydavnytstvo AN URSR [in Ukrainian].

Valenzuela, A. Moreno-García, M. \& Oliver, A. (2019). Archaeological and ethnographic insights on the occurrence and use of bone anvils in Mallorca (Belearic islands, Spaine). Cuadernos de Prehistoria y Arqueología de la Universidad de Granada (CPAG), 29, 293-306 [in English].

Valenzuela, A., Cau, M. \& León, M. (2017). Broadening the Scope of Bone Anvils: Direct AMS 14C Dating from the Island of Menorca (Western Mediterranean). Radiocarbon, 59 (1), 61-67 [in English].

Vukovic Bogdanovic, S. \& Bogdanović, I. (2016). Late Roman Bone Anvils from Viminacium. In Vitezović, S. (Ed.). Close to the bone: current studies in bone technologies. Belgrade: Institute of Archaeology, 66-70 [in English].

Vysotskaia, T. (1979). Neapol - stolitsa gosudarstva pozdnikh skifov [Naples is the capital of the late Scythian state]. Kyiv: Naukova dumka [in Russian].

\author{
Alisa Semenova \\ (Institute of Archaeology National Academy of Sciences of Ukraine, Kyiv, Ukraine) \\ e-mail: semenovaalise@gmail.com \\ ORCID: https://orcid.org/0000-0002-0809-3681
}

\title{
One Type of Bone Artifacts from Olbia and Its Interpretation
}

The study of bone and horn produced items often causes great difficulties for researchers, since it is difficult to determine accurately the true functional purpose of an artifact. In some cases, for example in such as we will describe in the paper, this problem can be solved using ethnographic data.

One of the most numerous categories of finished produced items made of organic raw materials is known in the Soviet, and later in Ukrainian, scientific literature under the term 'rashpil' (rasp).

The raw materials for these artifacts were mostly long (metatarsal, metacarpal, and bones of gaskin), less often flat (mandibular), bones of large domestic animals like horse and ox. Less often, deer antlers were used for these purposes. Tools made from the long bones of large mammals were usually first made plane pressing the diaphysis. One or more anatomical sides of the bone were processed, preserving the epiphysis or making it partially or completely plane. In the latter case, the shape of the produced item was close to a parallelepiped.

A characteristic feature of all these tools, regardless of the raw material and the degree of modification, are specific traces on the work surface - a series of parallel or chaotic lines of notches of subtriangular shape. They are applied, obviously, by some thin sharp tool. In the case when the 'rashpils' were made of metapodia, the tools with one, two, three, or four working surfaces can be found. A significant number of such artifacts were found in a broken, apparently in the process of operation, form. We know about cases of repeated use of one tool when after it lost the necessary work characteristics, the working surface was made plane again and reused.

Such tools come from many ancient sites of the Northern Black Sea region and Scythian settlements outside the Northern Black Sea region.

For a long time, they were mistakenly considered tools for processing ceramics, bone, tanning of hides, and even stone grinding. Their real purpose, as anvils to put teeth into serrated sickle blade sections, was established after analyzing large amounts of ethnographic data.

Keywords: Northern Black Sea region, Olbia, bone anvils, crafts, agriculture 

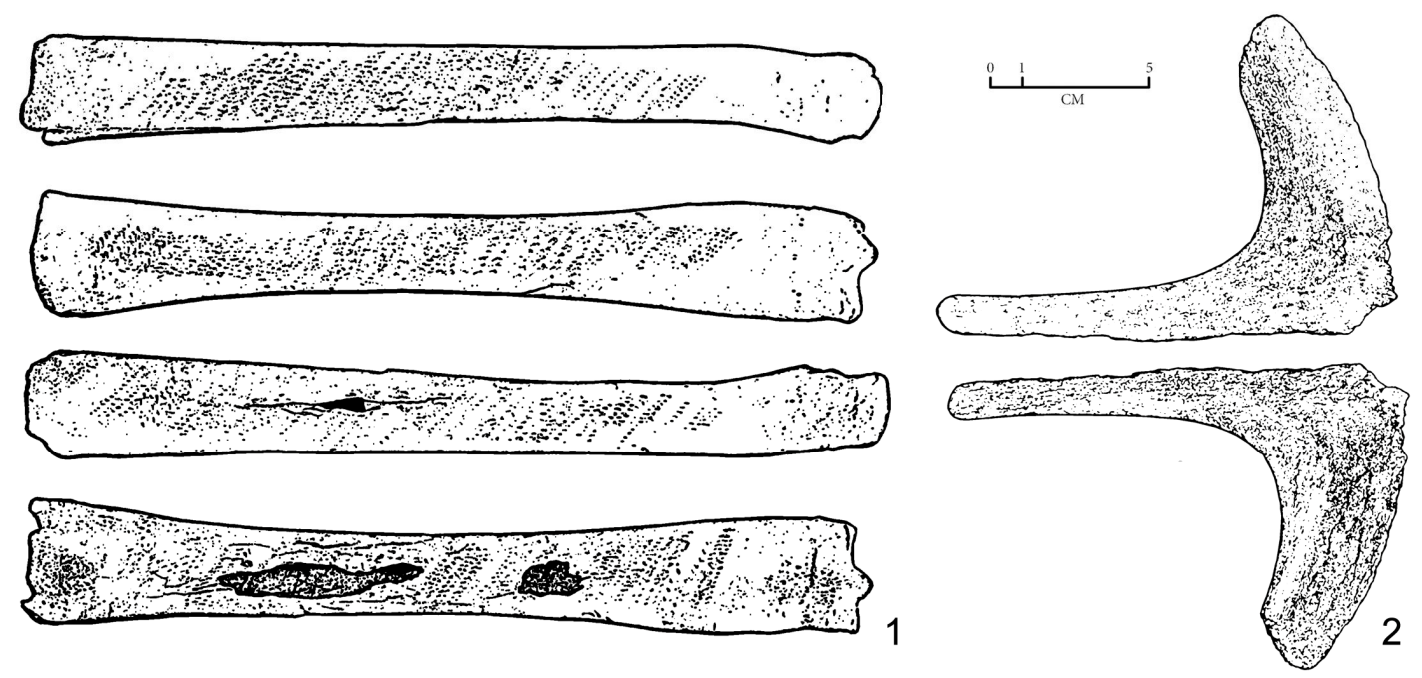

Рис. 1. Наковані для заточки гофрованих серпів.

1 - $з$ п’ясної кістка коня (0-71 № 1128); 2 - з рогу (оленя) (0-79 № 776). 

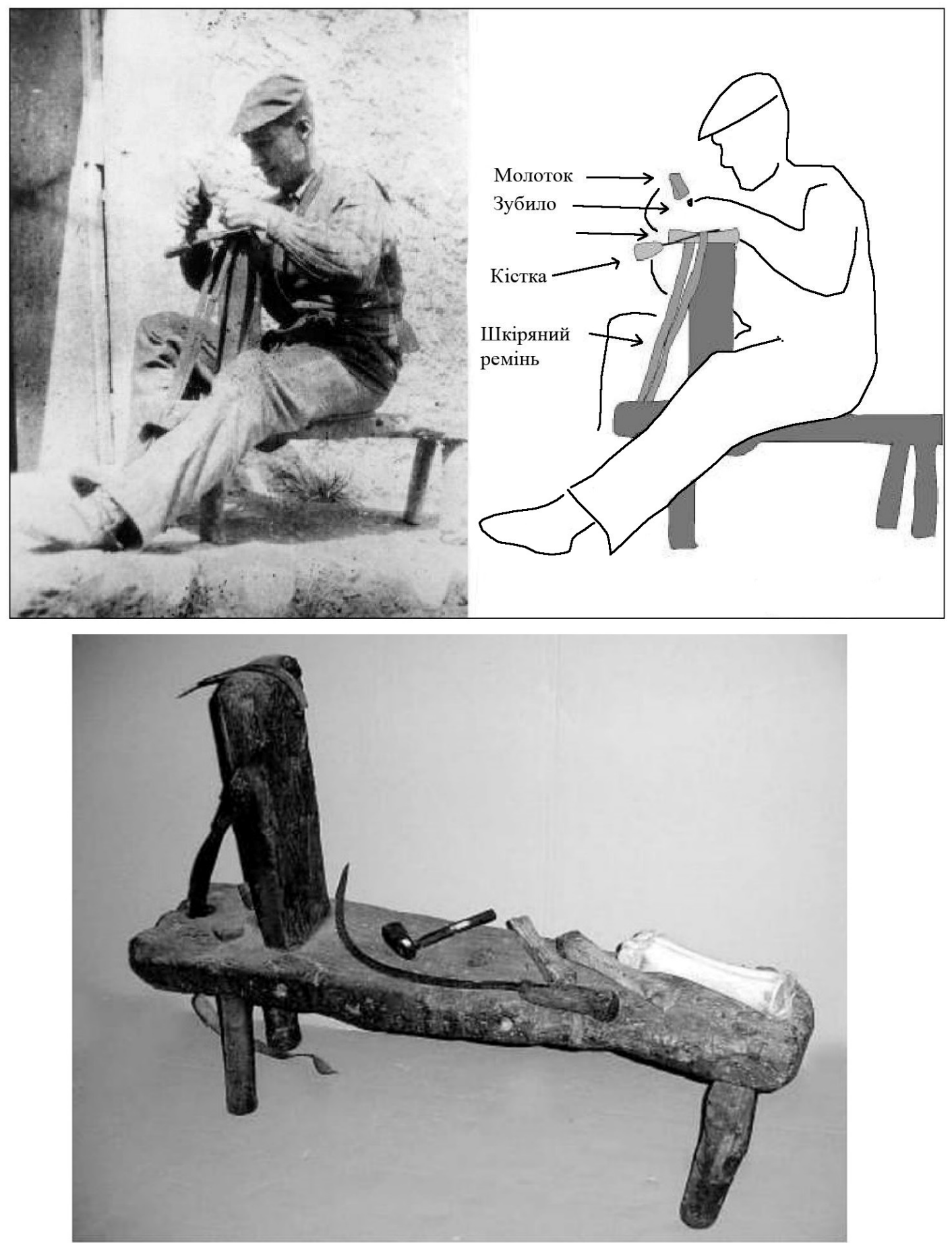

Рис. 2. Фото коваля за роботою та стіл для заточки гофрованих серпів 3 колекції музею Сан-Тельмо (Іспанія)

(за Aguirre et. al. 2004) 


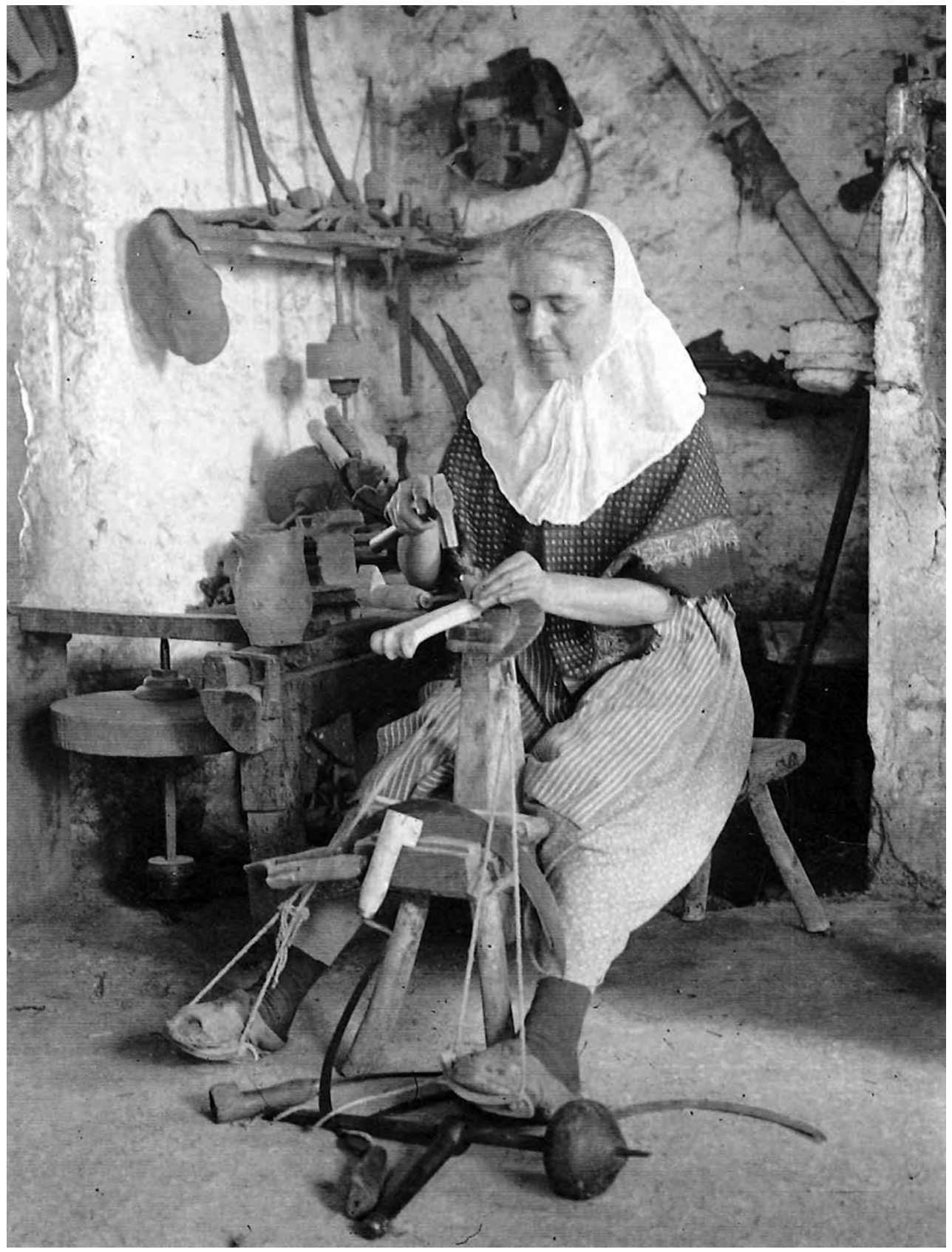

Рис. 3. Фото жінки за заточкою гофрованого серпа.

(за Valenzuela et. al. 2019) 

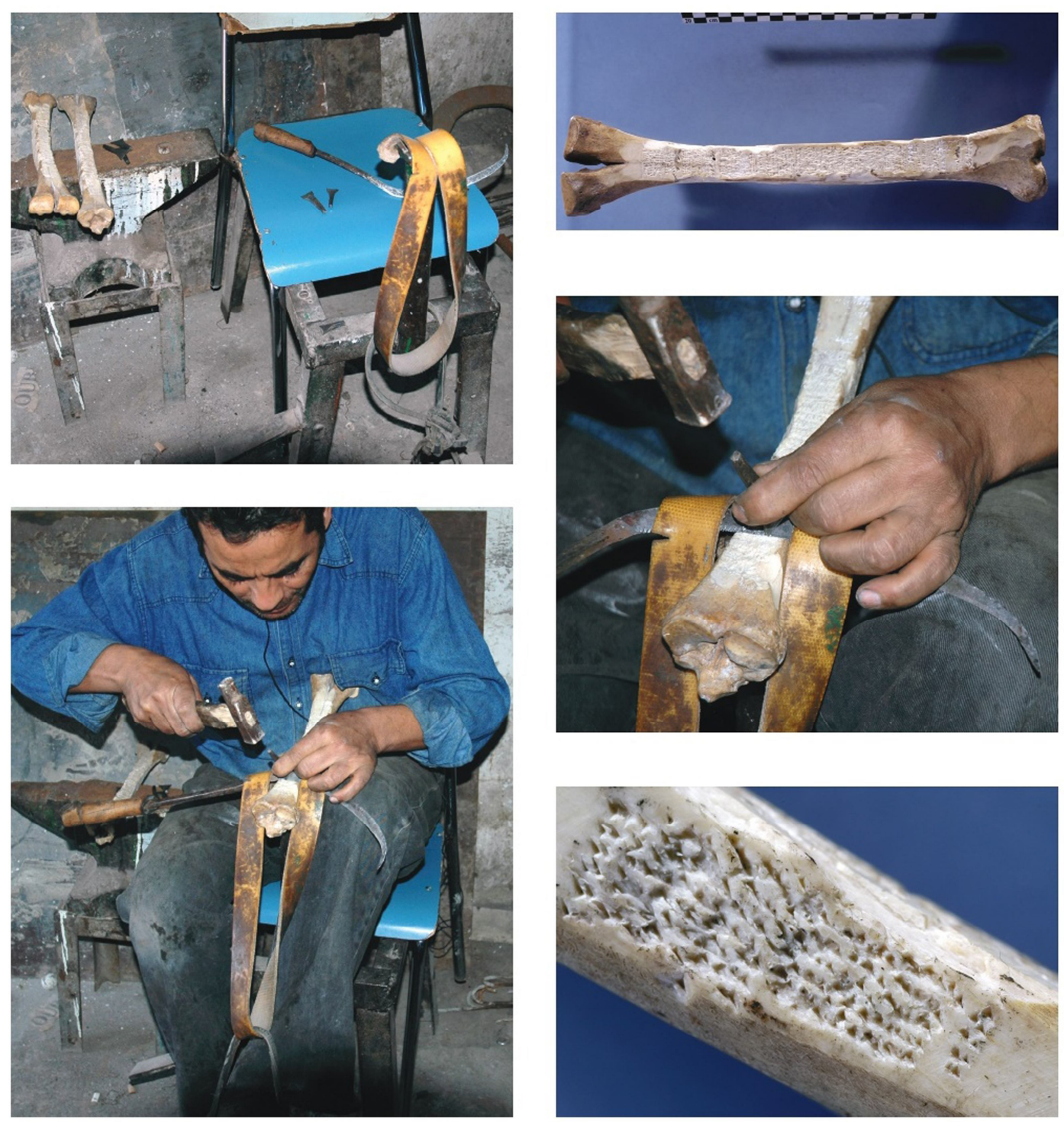

Рис. 4. Робочий інвентар і процес заточки серпа сучасного коваля з Тунісу.

(за Anderson et. al. 2014) 